\title{
Prevention of Cardiovascular Disease and Diabetes Mellitus In Low and Middle Income Countries
}

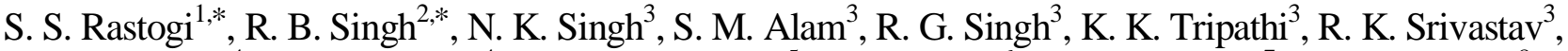 \\ S. K. Vajpeyee ${ }^{4}$, Hirdesh Gupta ${ }^{4}$, V. V. Muthusamy ${ }^{5}$, R. K. Goyal ${ }^{6}$, M. E. Yeolekar ${ }^{7}$, Adarsh Kumar $^{8}$, \\ N. S. Neki ${ }^{8}$, G. S. Sainani ${ }^{9}$, V. Shantaram ${ }^{10}$, Daniel Pella ${ }^{11}$, Jan Fedacko ${ }^{11}$, Fabien De Meester ${ }^{12}$, \\ T. K. Basu ${ }^{13}$, Surya Acharya ${ }^{13}$ and Lech Ozimek ${ }^{13}$
}

${ }^{1}$ Diabetes and Endocrine Centre, 112, Saini Delhi \& ${ }^{2}$ Halberg Hospital and Research Institute, Moradabad, India;
${ }^{3}$ IMS, BHU, Erclave, Varanasi; ${ }^{4}$ Government Medical College, Surat, India; ${ }^{5}$ Sugapriya Hospital, Madurai, India;
${ }^{6}$ Baroda University, Baroda; ${ }^{7}$ KEM Hospital, Mumbai; ${ }^{8}$ Government Medical College Amritsar, India, $;$ Jashlok Hospi-
tal, Mumbai, India; ${ }^{10}$ Nizam Institute of Medical Sciences, Hyderabad, India; ${ }^{11}$ PJ Safaric University, Kosice, Slovakia;
${ }^{12}$ Columbus Paradigm Institute, Waterloo, Belgium; $;{ }^{13}$ University of Alberta, Edmonton, Canada

\begin{abstract}
Hyperglycemia as a component of metabolic syndrome, appears to be an important risk marker of vascular disease in most developing countries which are under transition from poverty to affluence. Despite a moderate increase in fat intake and low rates of obesity, the risk of coronary artery disease (CAD) and diabetes is rapidly increasing in most of the developing economies. It is a paradox that in some of these countries the increased risk of people to diabetes and $\mathrm{CAD}$, especially at a younger age, is difficult to explain by conventional risk factors. It is possible that the presence of new risk factors especially higher lipoprotein (a)(Lpa), hyperhomocysteinemia, insulin resistance, low high density lipoprotein cholesterol and poor nutrition during fetal life, infancy and childhood may explain at least in part, the cause of this paradox. The prevalence of obesity, central obesity, smoking, physical inactivity and stress are rapidly increasing in low and middle income populations, due to economic development. In high income populations, there is a decrease in tobacco consumption, increase in physical activity and dietary restrictions, due to learning of the message of prevention, resulting into reduction in coronary and sroke mortality. Hypertension, (5-10\%) diabetes(3-5\%) and CAD(3-4\%) are very low in the adult, rural populations of India, China, and in the African sub-continent which has less economic development. However, in urban and immigrant populations of India and China, the prevalence of hypertension $(>140 / 90$, $25-30 \%)$, diabetes $(6-18 \%)$ and CAD (7-14\%) are significantly higher than they are in some of the high income populations. Mean serum cholesterol (180-200 mg/dl), obesity (5-8\%) and dietary fat intake (25-30\% en/day) are paradoxically not very high and do not explain the cause of increased susceptibility to CAD and diabetes in some South Asian countries. The force of lipid- related risk factors and refined starches and sugar appears to be greater in these populations due to the presence of the above factors and results into CVD and diabetes at a younger age in these countries. These findings may require modification of the existing American and European guidelines, proposed for prevention of CAD, in high income populations. Wild foods or designer foods (400-500g/day) substitution (www.columbus-concept.com) for proatherogenic foods; in conjunction with moderate physical activity and cessation of tobacco, may be protective against deaths and disability due to CVD and diabetes in most of these countries.
\end{abstract}

Keywords: Risk factor, inflammation, fruit, vegetable, diet.

\section{INTRODUCTION}

Coronary risk factors; such as hypertension, diabetes mellitus, tobacco consumption, hypercholesterolemia and obesity as well as coronary artery disease (CAD) are a major health problems in developed as well as in developing economies. Hyperglycemia as a component of metabolic syndrome or diabetes mellitus appears to be the major risk factor for vascular disease.

*Address correspondence to these authors at the Diabetes and Endocrine Center, 112, Saini Enclave, Delhi, India; E-mail: ssrastogi@yahoo.com and Halberg Hospital and Research Institute, Civil Lines, Moeradabad-10 (UP) 244001, India; Tel/Fax: 0091591 2417437; E-mail; icn2005@sancharnet.in
CAD was known to Indians around $600 \mathrm{BC}$, when great physicians Sushrut and Charak proposed that "overeating, excess of sleep, lack of exercise and anxiety may cause narrowing of channels in the body resulting into heart attack and death". The risk of cardiovascular disease (CVD); hypertension, stroke CAD and diabetes mellitus, is changing dynamically around the world. In the South Asian sub-continent, where type 2 diabetes and CAD are highly prevalent, it is clearly apparent that people of South Asian descent, around the globe have the highest rates of premature CAD, with clinical manifestations occurring about 10 years earlier than in other populations [1-4]. Over the past 50 years, several studies involving several generations, have consistently 
shown that the incidence and mortality rates for CAD are 50$300 \%$ higher among overseas South Asians compared with compatriots of other ethnicities [5-13].

\section{CAUSES OF MORTALITY}

In India [5], all causes mortality were; infectious diseases (41.1\%, $\mathrm{n}=915)$ such as tuberculosis, pneumonia, chronic obstructive pulmonary disease, diarrhea/dyssentary, hepatitis $\mathrm{B}$, inflammatory brain infections as the commonest cause of deaths in the urban population of north India. The second most common causes of deaths were circulatory diseases (29.1\%, $\mathrm{n}=646)$ including heart attacks $(10.0 \%)$, stroke (7.8\%), valvular heart disease $(7.2 \%, \mathrm{n}=160)$, sudden cardiac death and inflammatory cardiac disease,each $(2.0 \%, \mathrm{n}=44)$. Malignant neoplasm $(5.8 \%, \mathrm{n}=131)$, injury $(14.0 \%, \mathrm{n}=313)$ including accidents; fire and falls and poisonings, were also quite common causes of death. Miscellaneous causes of deaths were noted in $9.1 \%,(\mathrm{n}=202)$ death records, including diabetes mellitus $(2.2 \%, 49)$, suicides $(1.8 \%, \mathrm{n}=41)$, congenital anomalies $(1.0, n=37)$, dental caries infections $(1.9, n=42)$, and burns $(1.3 \%, \mathrm{n}=33)$. Pregnancy and perinatal causes $(0.72 \%, \mathrm{n}=15)$ were not commonly recorded in our study. Circulatory diseases as the cause of mortality were significantly more common among higher social classes 1-3 than in lower social classes 4 and 5 who died more often, due to infections. Heart attacks, stroke, hypertension, diabetes and obesity were significantly more common among higher social classes 1-3 compared to class 3 and 4 but tobacco intake showed only minor differences in various classes.

In one Indian report [7] in the year 1994 to 1998, trends indicate that there has been a significant decline of proportionate deaths from infectious diseases from $22 \%$ to $16 \%$. Cardiovascular disease (CVD) mortality increased from $21 \%$ to $25 \%$. This is lower than death rate of 29.1 reported by Singh et al. in 2005 [5]. In a recent verbal autopsy among 48,357 adults aged 25-69 years at Chinnae, deaths due to vascular diseases were $38.6 \%(\mathrm{n}=18,680)$, followed by cancer $(8.7 \%)$, tuberculosis (5.8\%), and respiratory causes (3.5\%). There were 1,354 deaths in another verbal autopsy study among 150,000 subjects, in the first year follow up. This study showed that circulatory diseases as the cause of death were noted in 34\% men and 30\% women. In a selected urban population from south India (9) among 1399 subjects (respondents 1262). Deaths were significantly greater among diabetics compared to nondiabetics (18.9 vs 5.3 per 1000 person years, $\mathrm{P}=0.004$ ) during a follow up of 6 years. Mortality due to CVD were $52.9 \%$ among diabetics and 24.2 among nondiabetics. is an urgency for prevention program due to increased burden of CVD in type 2 diabetes in India [4-11]. Conventional risk factors common among Indian immigrants to industrialized countries are not able to explain the cause of higher risk of CVD mortality among these populations [11-14]. International College of Cardiology, The Tsim Tsoum Institute, Poland, Indian Society of Hypertension and International College of Nutrition and other experts have proposed guidelines for prevention of CVD and diabetes in Indians and Asians. These guideline are modifications of the American guidelines so they can be used for public education by the health workers allover the world [15-21].

\section{PREVALENCE OF HYPERTENSION, TYPE-2 DIABETES AND CORONARY ARTERY DISEASE}

In 2007, world population was 6.6 billion including 1.3 billion South East Asians, which would increase to 7.9 billion and 1.6 billion respectively by the year 2025 . The population of adults, aged 20-79 years, was 4.1 billion in the world in the year 2007. This included 770 million South East Asians, which would increase to 5.2 billion and 1083 million respectively by the year 2025. In South East Asia, in the year 2007 , the prevalence of diabetes and prediabetes were about $6 \%$ each indicating that 46.5 million subjects above 20 years had this problem which would be doubled by the year 2025 . The burden of CAD would be similar but hypertension would be 4 fold greater compared to diabetes. According to new criteria, the prevalence of hypertension (>140/90 $\mathrm{mmHg}$ ) has been reported to be $22-30 \%$ in India among urban subjects above 20 years of age. In various cities according to nutritional status, the prevalence of CAD varies between $8 \%$ to $14 \%$. In rural population, the prevalences of diabetes, hypertension and CAD is 2-3 fold lower compared to urban communities [22-32].

\section{HYPERTENSION}

Of 600million adults, 420 million were rural and 180 million, urban in a 2001 census. The absolute number of hypertensives (>140/90) would be 31.5 million rural and 34 million urban, (total=65.5 million). Stage 1 , hypertension (>140-159/90-99) 45.5 million pre-hypertension (130$139 / 85-89)$ with $20 \%$ prevalence; 50 million. It may be estimated that 50 million subjects may diagnosed with prehypertension. These patients should be educated about lifestyle changes to prevent the development of hypertension. Drug therapy with ACE-inhibiters and and amplodipine calcium channel blocker may be given to rest 65.5 million along with lifestyle changes.

Table 1-5 reveal the prevalence of hypertension in India. The prevalence of hypertension was $6.8 \%$ in rural Haryana to $21.2 \%$ in rural Rajasthan. The prevalence was significantly greater in urban Trivandrum, South India compared to Moradabad in North India (Table 1). [23, 24, 27] Table 2 indicate that mean blood pressures of the population increased from $73.2 \mathrm{mmHg}$ diastolic in 1942 to 84.0 in 1997. The systolic mean blood pressure was $120.4 \mathrm{mmHg}$ in 1942, which increased to $130 \mathrm{mmHg}$ in 1997.

Mean systolic blood pressure was $125 \mathrm{mmHg}$ and diastolic $82 \mathrm{mmHg}$ in an urban women sample of 3212 subjects aged 25-64 years, as observed in the Five City study. Hypertension (>140/90 $\mathrm{mm} \mathrm{Hg}$ ) was significantly more common in south India and west India, compared to east, central and north India (Table 3). However, the overall prevalence of hypertension in the five cities was $25.6 \%(\mathrm{n}=823)$ among women (Table 4). Isolated systolic hypertension $2.9 \%(n=96)$, borderline, $14.9 \%$, isolated diastolic hypertension $50.5 \%$, definite hypertension $18.6 \%$ were also common. It seems that hypertension and its risk factors, have become an important public health problem in India. This is more clear from the data observed in the Five City Study (Table 1-4).

\section{BLOOD PRESSURE VARIABILITY}

Franz Halberg, Germaine Cornelissen and Othild S from Halberg Chronobiology Center, University of Minnesota 
Table 1. Prevalence of Hypertension in Rural and Urban Population of India (>140/90)

\begin{tabular}{|c|c|c|c|c|c|}
\hline \multicolumn{6}{|l|}{ Rural } \\
\hline - Gupta et al., & 1994 & $20-80$ & Rajsthan & 3148 & $21.2 \%$ \\
\hline -Singh et al., & 1997 & $20-65$, & UP, & 162 & $12.9 \%$ \\
\hline \multicolumn{6}{|l|}{ Urban } \\
\hline •Wasir et al., & 1995 & $20-75$ & Delhi & 679 & $6.2 \%$ \\
\hline -Gupta et al., & 1997 & $20-65$ & Rajasthan . & 2212 & $31 \%$ \\
\hline -Begum et al., & 1998 & $25-64$ & Trivandrum & 1497 & $30.7 \%$ \\
\hline •Singh et al., & 2010 & $>25$ & Five cities & 6940 & $28.9 \%$ \\
\hline
\end{tabular}

Modified from Singh et al., 2000.

Table 2. Rise in Mean Blood Pressure from 1942 to 1997 Among Adults in India

\begin{tabular}{|l|c|c|c|}
\hline Authors & Year & Systolic & Diastolic \\
\hline \hline$\cdot$ Chopra, & 1942, & 120.4, & 73.2 \\
\hline$\cdot$ Dotto, & 1949, & 121.6 & 82.0 \\
\hline$\cdot$ Dubey, & 1954, & 123.5 & 82.5 \\
\hline$\cdot$ Mathur, & 1963 & 126.2 & 79.4 \\
\hline$\cdot$ Malhotra, & 1971 & 126.2 & 79.4 \\
\hline$\cdot$ Sharma, & 1985 & 128.7 & 84.2 \\
\hline$\cdot$ Gupta & 1995 & 128.8 & 83.2 \\
\hline$\cdot$ Singh, & 1997 & 130.0 & 84.0 \\
\hline$*$ Singh et al., & 2011 & 132.2 & 85.5 \\
\hline$\cdot$ Correlation Coefficient $.=0.98,047, \mathrm{P}<0.001$ for Systolic,$=0.47$ for diastolic,P<0.021 & \\
\hline
\end{tabular}

Modified from Singh et al., 2000.

Table 3. Prevalence of Hypertension in Five Indian Cities

\begin{tabular}{|l|c|c|c|}
\hline$\cdot$ Area & $\mathbf{1 1 4 0 / 9 0}$ & $\mathbf{> 1 6 0 / 9 5}$ & Prehypertension \\
\hline \hline$\cdot$ North,Moradabad & $22.3 \%$ & $12.9 \%$ & $24.6 \%$ \\
\hline$\cdot$ South,Trivandrum & $30.7 \%$ & $18.1 \%$ & $32.2 \%$ \\
\hline$\cdot$ East,Calcatta & $19.1 \%$ & $11.8 \%$ & $21.3 \%$ \\
\hline$\cdot$ Central,Nagpur & $24.2 \%$ & $12.3 \%$ & $25.7 \%$ \\
\hline$\cdot$ West,Mumbai & $28.0 \%$ & $17.0 \%$ & $30.1 \%$ \\
\hline
\end{tabular}

Modified from Singh et al., Int J Cardiol, 1998. 
Medical School, Mineapolis, USA discovered new criteria for the diagnosis of vascular variability disorders (VVDs); circadian-hyperamplitude tension, MESOR hypertension and ecphasia. South Asians living in USA appear to have significantly greater risk of VVDs compared to Caucasians. Population surveys should be conducted with ambulatory blood pressure monitoring to demonstrate VVDs among various communities of the world.

Table 4. Risk Factors of Hypertension in Five Indian Cities

\begin{tabular}{|l|c|c|}
\hline RiskFactors, & Hypertensive & Normotensive \\
\hline \hline$\bullet$ Mean age,yrs (SD) & $44.2(15)^{*}$ & $36.8(12)$ \\
\hline$\bullet$ BMI,Kg/M2, (SD) & $24.2(2.7)^{* *}$ & $22.2(2.7)$ \\
\hline$\cdot$ Sedentary, & $89.9 \% * *$ & $40.9 \%$ \\
\hline Salt intake & $87.9 \% *$ & $47.8 \%$ \\
\hline$\bullet$ Alcohol & $20.5 \% *$ & $5.2 \%$ \\
\hline
\end{tabular}

Modified from Singh et al., 2007.

\section{TYPE 2 DIABETES MELLITUS}

Table 5, shows the prevalence of type 2 diabetes mellitus which was quite low before 1984 among both rural (1.6 $2.4 \%$ ) and urban (3.4-4.5\%) populations of India. The prevalence of diabetes showed marked increase in the last two decades in India and other developing countries. Type 2 diabetes was; $5 \%$ at Kudremukh as observed by Ramchandran et al. in 1988 which increased to $14.3 \%$ in Madras by 2006 (Table 5). Insulin resistance appears to be a risk factor of type 2 diabetes, hypertension and CAD among South Asians [36-38].

\section{CORONARY ARTERY DISEASE}

People of South Asian origin wherever they are living develop clinical manifestations of coronary atherosclerosis at a younger age which often have a malignant course [34, 35]. It is noteworthy that, about $50 \%$ of the first MI occur before the age of 55 years and $25 \%$ occur before 40 years of age. South Asians in England, younger than 30 years of age, have 3 fold higher CAD mortality than whites and in Singapore, 10-fold higher deaths than Chinese. The risk factor adjusted CAD rates are two fold greater among overseas south Asians

Table 5. Prevalence of Type-2 Diabetes in India

\begin{tabular}{|c|c|c|c|c|}
\hline Year & Author & Place & Urban \% & Rural\% \\
\hline 1971 & Tripathi et al., & Cuttack(Central) & 1.2 & - \\
\hline 1979 & Gupta et al., & Multicentre & 3.0 & 1.9 \\
\hline 1984 & Murthy et al., & Tenali(South) & 4.7 & - \\
\hline 1988 & Ramchandran et al., & Kudremukh(South) & 5.0 & - \\
\hline 1989 & Kodall et al., & Gangavathi(South) & - & 2.2 \\
\hline 1989 & Rao et al., & Eluru(South) & - & 1.6 \\
\hline 1991 & Ahuja et al., & New Delhi(North) & 6.7 & - \\
\hline 1997 & Ramchandran et al., & Madras(South) & 11.6 & - \\
\hline 1998 & Singh et al., & Moradabad & 6.0 & 2.9 \\
\hline 2000 & Rammurthy et al., & Kerala(South) & 12.4 & 2.5 \\
\hline 2001 & Ramchandran et al., & National(DESI) & 12.1 & - \\
\hline 2001 & Iyer et al., & Dombivill & 6.2 & - \\
\hline 2004 & Sadikot et al., & National & $5.9(4.3)$ & 2.7 \\
\hline 2006 & Mohan et al., & Chennai & 14.3 & - \\
\hline
\end{tabular}


compared to Caucasians [1-4, 17-35]. There has been a ten fold increase in the prevalence of CAD in the last three decades in the urban population of India and it appears to be as common as in developed countries. In rural areas, a three fold lower prevalence of CAD has been observed compared to cities.

In both rural and urban subjects, the prevalence of CAD was higher in South India, compared to North India. According to a study conducted in five different corners of India, CAD has become an important concern in south Asia. Compared to rural areas, CAD was three fold more common in the urban north India at Moradabad (9.0\%), four fold more common in urban south Indians at Trivandrum (13.9\%), and Mumbai $(11.6 \%)$, in west India, Nagpur $(10.0 \%)$ in central India and Kolkotta(8.2\%) in east India. Social classes 1-3, have greater risk of CAD, type 2 diabetes and hypertension, than lower social classes in both rural and urban populations of south Asia. We have reported a paradox paradox that dietary intakes and physical activity explain only a part of differences in prevalence and risk of CAD, hypertension and diabetes in people of south Asia wherever they are living (Table 6-8).

Table 6. Prevalence \% of Coronary Artery Disease and Coronary Risk Factors in South Asians and British

\begin{tabular}{|c|c|c|c|c|c|c|}
\hline & \multicolumn{2}{|c|}{ North Indians } & \multirow{2}{*}{$\begin{array}{c}\text { South Indians } \\
\text { Urban }\end{array}$} & \multirow{2}{*}{$\begin{array}{c}\text { Sri Lanka } \\
\text { Urban }\end{array}$} & \multirow{2}{*}{$\begin{array}{c}\text { UK South } \\
\text { Asians }\end{array}$} & \multirow{2}{*}{$\begin{array}{l}\text { Native } \\
\text { British }\end{array}$} \\
\hline & Rural & Urban & & & & \\
\hline Coronary Artery Disease & 3.0 & 9.0 & 13.9 & 11.5 & 15.0 & 6.0 \\
\hline Smoking $(\%)($ Men $)$ & 302 & 5.6 & 44.6 & 57.4 & 22 & 30 \\
\hline Diabetes $(\%)$ & 2.3 & 6.0 & 12.0 & 5.8 & 19.0 & 5.0 \\
\hline Hypertension $(<140 / 90 \mathrm{mmHg})(\%)$ & 10.0 & 25.0 & 30.0 & 27.2 & 28.0 & 30.0 \\
\hline Total Fat (kcal daily) & 14.8 & 24.7 & 28.8 & 28.0 & 38.8 & 42.2 \\
\hline Saturated Fat (\% kcal daily) & 4.9 & 9.2 & 14.4 & 13.6 & 13.7 & 18.5 \\
\hline Cholesterol in diet (mg daily) & 53 & 166 & 240 & 210 & 200 & 405 \\
\hline Body Mass Index (kg/m2) & 21.6 & 22.9 & 22.7 & 21.0 & 26 & 26 \\
\hline Waist-Hip Ratio (Male) & 0.86 & 0.89 & 0.89 & - & 0.98 & 0.94 \\
\hline Fasting Plasma Insulin (Male) (mU/L) & 4.8 & 5.1 & 16.6 & - & 9.8 & 7.2 \\
\hline 2-Hour after Glucose (mU/L) & 11.8 & 24.2 & 60.6 & - & 41.0 & 19.0 \\
\hline Serum Cholesterol (mg/dl) & 168 & 190 & 210 & 196 & 230 & 236 \\
\hline HDL Cholesterol (mg/dl) & 43.5 & 44.2 & 45.1 & 45.2 & 45.0 & 46.2 \\
\hline Angiotensin Converting Enzyme (IU) & 37.5 & 63.4 & 72.0 & - & 80.0 & - \\
\hline TNF-alpha(pg/ml) & 4.5 & 15.6 & 18.8 & & & \\
\hline IL-6(pg/ml) & 2.8 & 11.5 & 14.4 & - & - & - \\
\hline Nitrite(umol/L) & 1.0 & 0.76 & 0.67 & - & - & - \\
\hline
\end{tabular}

Values are means, Modified from Singh et al., [24] Lancet, 1995,J Nutr Environ Med 2001,Biomed Pharmaco 2004.HDL = High Density Lipoprotein Cholesterol.

Table 7. Genetic and Other Specific Risk Factors Common in South Asians for Unexplained Heart Disease

\begin{tabular}{|c|c|}
\hline Genetic or Environmental & Other Risk Factors \\
\hline 1. Insulin resistance and hyperinsulinemia & 1. Increased plasminogen activator inhibitor-1 \\
\hline 2. Poor beta cell function & 2. Decreased tissue plasminogen activator \\
\hline 3. Increased prevalence of type II diabetes & 3. Decreased antioxidant vitamins $\mathrm{A}, \mathrm{C}$, beta-carotene, $\mathrm{E}, \mathrm{Se}, \mathrm{Zn}$, flavonoids, other polyphenolics, amino acids. \\
\hline 4. Increased lipoprotein(a) & 4. Low high density lipoprotein cholesterol \\
\hline 5. Increased angiotensin converting enzyme & 5. Elevated homocysteins \\
\hline 6. High Apo-B & 6. Low Apo A1 \\
\hline \multirow{3}{*}{$\begin{array}{l}\text { 7.Influence on methylation of genes by } \\
\text { betain, vitamin B12, folic acid and w-3 fatty acids. }\end{array}$} & 7. Increased heart rate and BP variability \\
\hline & 8. Increased small dense LDL cholesterol \\
\hline & 9.Increased $w-6 / w-3$ ratio in the diet. 1:50 due to increased intake of sun flower, corn and soya bean oils. \\
\hline
\end{tabular}


Table 8. Dietary Guidelines and Desirable Level of Risk Factors for Indians

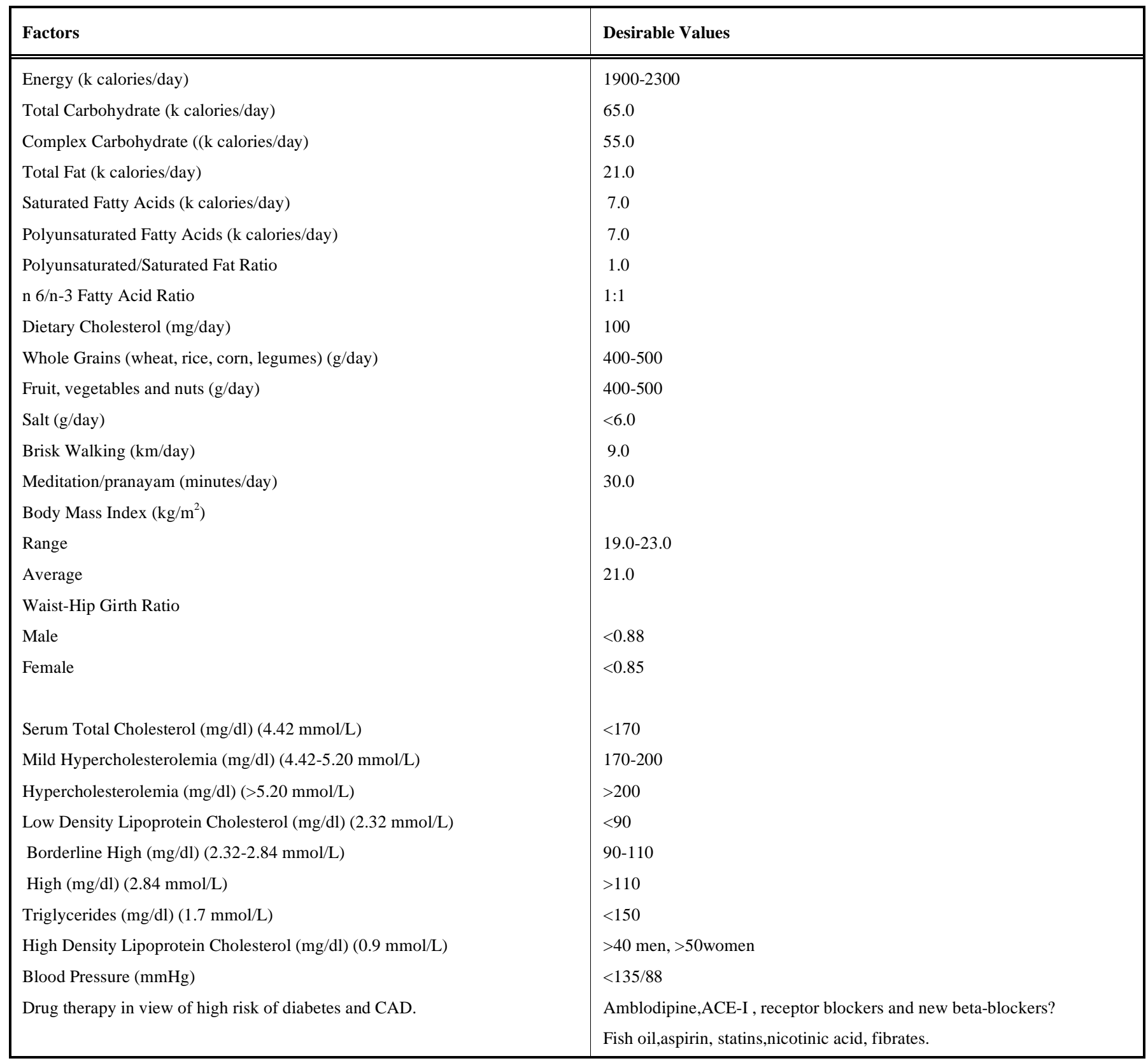

Modified from Indian Consensus Group, J Nutr Environ Med, 1996, World Heart Journal 2009.

\section{RISK FACTORS}

CAD rates are similar among both vegetarians and nonvegetarians among people of south Asia. Interestingly, Western vegetarians tend to have very low rates of CAD which may be due to increased intake of fruits and vegetables by these populations. The increased risk of south Asians to CAD and type 2 diabetes may be due to a possible molecular susceptibility. The western vegetarian diet is rich in fruits and vegetables, and non-vegetarian diets are rich in trans fat, saturated fat, w- 6 rich oils and cholesterol as well as refined carbohydrates which may be proinflammatory. The Indian vegetarian diet is grain based with some vegetables. In urban areas, refined bread, biscuits, candies, syrups, sweats, milk products; butter (saturated fat), clarified butter
(Cholesterol oxide)and vegetable ghee which is trans fatty acids as well as w-6 rich oils; sunflower, corn and soya bean oil are commonly used in the diets. These foods are known to have proinflammatory effect resulting in to increased risk of CVD and diabetes. Decline in beta cell functions, insulin resistance, and hyperinsulinemia, increased prevalence of type 2 diabetes, increased Lp (a), increased plasminogen activator inhibitor-1 and apo B lipoprotein, higher VLDL and low HDL cholesterol appear to be important in increasing the risk of CAD and diabetes in south Asia (Table 7). Higher levels of tumor necrosis factor-alpha, interleukin 6, interleukin-18 and high sensitive C-reactive proteins, angiotensin converting enzyme activity $(39.5+4.6$ vs $65.5+7.8$ $\mathrm{IU}, \mathrm{P}<0.03)$ in rural and urban subjects respectively, have been proposed to be important new risk factors of CVD and 
diabetes in Indians [3, 15, 16, 21-41]. High activity of ACE observed in Indian urban populations poses the possibility that ACE-I, could be important in the prevention of CVD and diabetes among south Asians. The risk, extent and prevalence, of atherogenesis, case fatality in acute coronary syndrome and mortality due to $\mathrm{CAD}$ is higher in south Asia, although they have low total cholesterol (150$200 \mathrm{mg} / \mathrm{dl})$, low body mass index $(21-23 \mathrm{Kg} / \mathrm{M} \mathrm{2})$, low fat intake (21-30\% en/day), lower prevalence of hypertension, lower prevalence of obesity (5-7\%), and moderate smoking among Asians, (compared to Caucasians), [25-41].

Populations adapted to survive in scarcity, on low fat intake and physically demanding occupations may develop conservatory mechanisms during transition from poverty to affluence [42-44]. Therefore, low intake of w-3 fatty acids, coenzyme Q10, antioxidant vitamins, essential amino acids and phytochemicals and high intake of w- 6 fatty acids (w6/w-3 ratio $>50$ ) and refined carbohydrates may predispose these communities to CVD and diabetes at modest increase in the primary risk factors which rapidly increase the secondary risk factors. In several randomized, controlled intervention trials, Singh and coworkers used $400 \mathrm{~g} / \mathrm{day}$ of fruits, vegetables, and legumes in conjunction with mustered oil to decrease the risk of hypertension, diabetes and CAD in 1090s [45]. DASH investigators in their studies re-examined this diet, to decrease the risk of hypertension in United States, [46, 47]. Singh observed that increasing dietary potassium and magnesium intake may increase tissue levels of these nutrients causing reduction in blood pressures.

In further trials, Singh et al. provided $400 \mathrm{~g} /$ day of fruits, vegetables and nuts (almonds and walnuts) and another $400 \mathrm{~g} /$ day of whole grains including legumes in conjunction with $25-50 \mathrm{~g} / \mathrm{day}$ of mustered oil in patients with high risk of vascular disease. These studies reported significant benefit due to increased intake of phytochemicals [48-50]. Other workers also found a beneficial effect of fruit, vegetables, nuts and w-3 fatty acids rich foods on risk of CVD [51-67]. Mono-unsaturated fatty acids and w- 3 fatty acids have been suggested to be protective against diabetes and metabolic syndrome [62-66]. However, greater intake of trans fatty acids, saturated fat and refined starches can predispose CVD and diabetes [42-67]. Rapid economic development in south Asia is associated with higher intake of salt, tobacco, fat, sugar, omega-6 rich oils and energy in the last forty years. Increase in per capita income, gross domestic product, food production and automobile production in the last four decades have also been observed with increase in socioeconomic status. There have been marked changes in diet and lifestyle, during the period of 1970 to 2010 , particularly in the urban populations, which may be the cause of the epidemic of CVD and diabetes among middle and higher income populations [2-10].

\section{GUIDELINES FOR PREVENTION}

The diet and lifestyle guidelines for prevention of CAD, hypertension and diabetes mellitus by the American agencies and WHO have been of great interest for the last few decades. American Diabetes Association and AHA, as well as by WHO guidelines have been reformed for better understanding, based on new scientific evidence which has emerged after there publication in 2000. Most US health agencies as well as by WHO have altered the targets for ideal blood pressure, blood glucose and blood cholesterol depending upon new evidence. These guidelines do not appear to be final and are likely to be altered in near future.

Most of the agencies do not emphasize on the role of diet in patients with acute myocardial infarction (AMI) [68-70]. AMI patients, due to their serious condition, are highly motivated to follow what is being advised by the cardiologist. It is easy to change health behaviours of the victims when they are admitted in the intensive cardiac care unit, to follow the same diet when they go back home. Hyperglycemia, hyperinsulinemia, hypertriglyceridemia, free radical stress, rise in free fatty acid and proinflammatory cytokines, leading to endothelial dysfunction are common in AMI patients [6776]. There is an acute generation of proinflammatory milieu among AMI patients which is known to cause disruption of atheroma plaque, resulting into reinfarction and death [2-4].

Dietary patterns; including grains, vegetables, fruits, nuts, seeds and legumes, fat and oils based on two renouned studies, have been advised by the American experts $[68,75]$. Since refined starches are known to cause endothelial dysfunction, this recommendation is no more given $[69,70]$. It is important to provide advise on the type of oil and type of nuts containing w-3 fat and monounsaturated fatty acid (MUFA) content of these foods. Refined starches, added sugar as well as excess of w-6, total and saturated fat and trans fatty acids are proinflammatory. However, increased intake of w-3 fatty acid and MUFA may be protective against surge of TNF-alpha, IL-6,IL-18 and adhesion molecules like VCAM-1(vascular cell adhsion molecule-1)and IVAM-1 caused by high glycemic, rapidly absorbed foods [71-76]. Such foods may initiate a proinflammatory milieu in the body which is similar to that of AMI and diabetes mellitus, causing further increase in complications, among these patients.

The Columbus Paradigm Institute (www.columbusconcept.com) and the the Tsim Tsoum Institute (www. tsimtsoum.net) have proposed a low w-6/w-3 ratio and polyunsaturated/saturated fatty acid ratio in the diet of $1: 1$ for prevention of dyslipidemia and CAD. It seems that this weakness in the guideline may be due to missing of related work [54-58, 71-75]. The greatest weakness of the American guidelines is that there is no discussion on proinflammatory foods, so there is opportunity for the industry to influence the consumers without consideration of their health.

Whole grains, vegetables, fruits, nuts and fish are good for prevention of obesity, hyperlipidemia, inflammation and hypertension as well as for prevention of dyslipidemia and metabolic syndrome and CAD. These foods inhibit the rise in FFA, hyperglycemia and maintain good endothelial function [74, 75]. Dietary cholesterol recommendations, are overemphasized, although it is well known that it has minor influence on atherothrombo-genesity of serum LDL. Columbus foods are natural foods, rich in phytochemicals which are slowly absorbed without causing any abnormal increase in blood glucose, insulin, proinflammatory cytokines and free fatty acids and can decrease atherogenesity of LDL [74, 75]. A return of alpha-linolenic acid (ALA, C18:303) in the diet- herein referred to as wild- or game-type land-based 
fatty acid - into the feed ration of land-based bred animals to such an extent that their fat depots (white adipose tissue) exhibit a balanced ratio of essential fatty acids, i.e. $\omega 6: \omega 3=$ $1: 1$, is the basis of Columbus ${ }^{\circledR}$ concept. It is a characteristic of fat depots in wild animals or game.

This alteration may cause a substantial reduction in long chain omega- 6 fatty acids and a moderate species-specific increase in long chain omega-3 fatty acids in organs and peripheral tissues of these domesticated animals or livestock. It seems that in all eatable fats, the $\omega 6: \omega 3=1: 1$ ratio should be taken as reference for the design of composite plant-derived table oils and fats for cooking and grilling of foods. These oils represent other primary sources of energy in the modern human diet but a particular attention is drawn to the antioxidant and essential amino acid content of such foods. The end results may be a return to animal and plant food supplies in better compliance with human genetic heritage and a possible rehabilitation of dietary cholesterol and saturated fats (former CSI, C: Cholesterol, S: Saturated fats, I: Index).

The Columbus ${ }^{\circledR}$ Concept stands for the return of a specific healthy cholesterol into men's food supply and blood stream, which may be called wild or game cholesterol that is associated with a dietary balanced essential fatty acid ratio $(\omega 6: \omega 3=1: 1)$ [54-58]. In a natural untamed environment, nature recommends the consumption of a balanced ratio of saturated and polyunsaturated fatty acids as part of a dietary lipid pattern rich in monounsaturated fatty acids (P:M:S = $1: 6: 1)$. It has also been proven in long term dietary trials [39, 44-54, 60, 74]. Recently, US department of health and human services has issued guidelines for physical activity for Americans which need assessment by this joint consensus for application in South Asians [76, 77]. Cornelissen et al. have suggested the need for consideration of blood pressure variability disorders [78] and others about extent of type 2 diabetes mellitus [79]. In one experience (RBS), eating 50$60 \mathrm{~g} /$ day of walnut caused significant reduction in blood pressures from $141 / 92 \mathrm{~mm} \mathrm{Hg}$ to $130 / 88 \mathrm{~mm} \mathrm{Hg}$ in about 8 weeks [80]. In several recent studies, a role for dietary patterns has been proposed in CVD and diabetes [80-90].

In brief, eating $400 \mathrm{~g} /$ day of fruits, vegetables and nuts (almonds and walnuts 50g/day), another $400 \mathrm{~g} /$ day of whole grains including legumes in conjunction with $25-50 \mathrm{~g} / \mathrm{day}$ of mustered oil or Columbus oil (olive oil+lin seed oil) may be protective for prevention of type 2 diabetes, hypertension, stroke and CAD. (Table 8) Regular spot running and meditation (each 30min) and cessation of tobacco intake are also important for prevention of these diseases. Alcohol intake in moderation, particularly red wine rich in reveratrol flavonoids may be more beneficial as proposed in the French paradox by Searge Renaud [80-84]. These diet and lifestyle changes can influence mind-body connections and have been better approached in the Tsim Tsoum concept which is an extention of the Columbus concept $[54,85]$. Such diets and lifestyle have also been advised in ancient India and China and by WHO.

\section{ACKNOWLEDGEMENTS}

Acknowledgements are due to international college of nutrition and international college of cardiology for support to write this work.

\section{REFERENCES}

[1] World Health Organization. Preventing Chronic Disease: A Vital Investment World Heath Organization, Geneva 2005.

[2] Indrayan A. Forecasting vascular disease cases and associated mortality in India 2007; http://www.whoindia.org/LinkFiles/ Commision on Macroeconomic and Health Bg P2 Forecasting vascular disease cases and associated mortality in India.pdf: [Accessed November 6, 2008].

[3] Pella D, Thomas N, Tomlinson B, Singh RB. Prevention of coronary artery diseases: the South Asian paradox. Lancet 2003; 361: 79 .

[4] American Heart Association Heart and Stroke Statistical Update, 2008. http://www.americanheart.org/downloadable/heart/ 120007 8608862HS Stats\%202008.final.pdf

[5] Singh RB, Singh V, Kulshrestha SK, et al. Social class and all cause mortality in the urban population of north India. Acta Cardiol 2005; 60: 611-7.

[6] Gupta R, Mishra A, Pais R, et al. Correlation of regional cardiovascular mortality in India with lifestyle and nutritional factors. Int J Cardiol 2006; 108: 291-300.

[7] Gazalakshmi K, Peto R, Kanaka S, et al. Verbal autopsy of 48,000 adult deaths attributable to medical causes in Chennai, India. BMC Public Health 2002; 2: 7.

[8] Joshi R, Cardona M, Iyengar S, et al. Chronic diseases now a leading cause of death in rural India: mortality data from Andhra Pradesh rural initiative. Int J Epidemiol 2006; 35: 1522-9.

[9] Mohan V, Shanthirani CS, Deepa M, Deepa R, Unnikrishnan RI, Datta M. Mortality rates due to diabetes in a selected urban south Indian population- The Chennai urban population study(CUPS-16). J Assoc Physicians India 2006; 54: 113-7.

[10] Goyal A, Yusuf F. The burden of cardiovascular disease in the Indian subcontinent. Ind J Med Res 2006; 124: 235-44.

[11] Chaturvedi N, Fuller JH. Ethnic differences in mortality from cardiovascular disease in the UK: do they persist in people with diabetes? J Epidemiol Commun Health 1996; 50: 137-9.

[12] Chaturvedi N, Jarrett J, Morrish N, Keen H, Fuller JH. Differences in mortality and morbidity in African Caribbean and European people with non-insulin dependent diabetes mellitus: results of 20 year follow up of a London cohort of a multinational study. BMJ 1996; 313: 848-52.

[13] Forouhi NG, Sattar N, Tillin T, McKeigue PM, Chaturvedi N. Do known risk factors explain the higher coronary heart disease mortality in South Asian compared with European men? Prospective follow-up of the Southall and Brent studies, UK. Diabetologia 2006; 49: 2580-8.

[14] Enas EA, Singh V, Munjal YP; et al. Reducing the burden of coronary artery disease in India. Ind Heart J 2008; 60: 161-75.

[15] Indian Consensus Group: Indian consensus for prevention of hypertension and coronary artery diseases: a joint scientific statement of Indian Society of Hypertension and International College of Nutrition. J Nutr Environ Med 1996; 6: 309-18.

[16] Singh RB, Mori Hideki, Chen Junshi, et al. Recommendations for the prevention of coronary artery disease in Asians: a scientific statement of the International College of Nutrition. J Cardiovasc Risk 1996; 3: 489-94.

[17] Bhalodkar NC, Blum S, Rana T, Bhalodkar A, Kitchappa R, Enas EA. Effect of leisure time exercise on high-density lipoprotein cholesterol, its subclasses, and size in Asian Indians. Am J Cardiol 2005; 96: 98-100.

[18] Singh RB, Rastogi SS, Rao PV, et al. Diet and lifestyle guidelines and desirable levels of risk factors for the prevention of diabetes and its risk factors in Indians: A scientific statement of the International College of Nutrition. J Cardiovasc Risk 1997; 4: 201-8.

[19] Beaglehole R, Ebrahim S, Reddy S, Voute J, Leeder S. Prevention of chronic diseases: a call to action. Lancet 2008; 370: 2152-7.

[20] Epping-Jordan JE, Galea G, Tukuitonga C, Beaglehole R. Preventing chronic diseases: taking stepwise action. Lancet 2005; 366: 1667-71.

[21] Pella D, Singh RB, Tomlinson B, Kong CW. Coronary artery disease in developing and newly industrialized countries: a scientific statement of the International College of Cardiology. In: Dhalla NS, Chocklingham A, Berkowitz HJ, Singal PK, Eds. Frontiers of Cardiovascular Health, Boston Kluwer Academic Publishers 2003; pp. 473-83.

[22] Ramchandran A. Rising prevalence of diabetes in India and the implications of ADA-EASD Consensus on the management. 
MediPrevention of Cardiovascular Disease and Diabetes Mellitus Open Nutraceuticals J 2010; 3(9): 2007; 17: 180-4.

[23] Singh RB and the Five City Study Group. Prevalence and risk factors of hypertension and age-specific blood pressures in five cities: a study of Indian women. Int J Cardiol 1998; 63: 165-73.

[24] Singh RB, Suh IL, Singh VP, et al. Hypertension and stroke in Asia:prevalence, control and strategies in developing countries for prevention. J Hum Hypertens 2000; 14: 749-63.

[25] Beegom R, Singh R. Prevalence of coronary heart disease and its risk factors in the urban population of South India. Acta Cardiol 1995; 50: 227-40.

[26] Singh RB, Ghosh S, Niaz MA, et al. Epidemiologic study of diet and coronary risk factors in relation to central obesity and insulin levels in the urban population of North India. Int J Cardiol 1995; 47: 245-55.

[27] Mendis S, Lindholm LH, Mancia G, et al. World Health Organization(WHO) and International Society of Hypertension(ISH) risk prediction charts: assessment of cardiovascular risk for prevention and control of cardiovascular disease in low and middle income countries. J Hypertens 2007; 28: 1578-82.

[28] Singh RB, Beegom R, Mehta AS, et al. Social class, coronary risk factors and undernutrition, a double burden of diseases in women during transition in five Indian cities. Int J Cardiol 1999; 69: 139-47.

[29] Gupta R, Gupta VP. Metaanalysis of coronary heart disease prevalence in India. Ind Heart J 1996; 48: 241-5.

[30] Singh RB, Rastogi V, Niaz MA, Ghosh S, Sy RG, Janus ED. Serum cholesterol and coronary artery disease in populations with low cholesterol levels: the Indian paradox. Int J Cardiol 1998; 65: 81-90.

[31] Singh RB, Pella D, Neki NS, Rastogi S, Mori H, Otsuka K. Mechanism of acute myocardial infarction study(MAMI Study). Biomed Pharmacol J 2004; 38(Supple): 111-5.

[32] Singh RB, Sharma JP, Rastogi V, et al. Social class and coronary artery disease in a rural population of North India. The Indian Social Class and Heart Survey. Eur Heart J 1997; 18: 1728-35.

[33] Singh RB, Verma SP, Niaz MA. Social class and coronary artery disease in India. Lancet 1999; 353: 154-5.

[34] Singh RB, Rastogi SS, Rastogi V, et al. Blood pressure trends,plasma insulin levels and risk factors, in rural and urban elderly populations of north India. Coronary Art Dis 1997; 8: 463-8.

[35] Singh RB, Pella D, Sharma JP, et al. Increased concentrations of lipoprotein(a),circadian rhythms and metabolic reactions, evoked by acute myocardial infarctions, in relation to large breakfast. Biomed Pharmacother 2004: 58(Supple): 116-22.

[36] Singh RB, Rastogi SS, Verma R, et al. Randomized, controlled trial of cardioprotective diet in patients with acute myocardial infarction : results of one year follow up. BMJ 1992; 304: 1015-9.

[37] Singh RB, Pella D, Kartikey K, DeMeester, F and the Five City Study Group. Prevalence of obesity, physical inactivity and undernutrition, a triple burden of diseases,during transition in a middle income country. Acta Cardiol 1997; 62: 119-27.

[38] Singh RB, Niaz MA, Ghosh S, et al. Association of trans fatty acids(vegetable ghee), and clarified butter (Indian ghee) intake with higher risk of coronary artery disease, in rural and urban populations with low fat consumption. Int J Cardiol 1996; 56: 289-98.

[39] Singh RB, Otsuka K, Chiang CE, Joshi SR. Nutritional predictors and modulators of metabolic syndrome. J Nutr Environ Med 2004; 14: 3-16.

[40] Singh RB, Sircar AR, Rastogi SS, Singh R. Dietary modulators of blood pressure in hypertension. Eur J Clin Nutr 1990; 44: 319-27.

[41] Singh RB, Beegom R,Verma SP, et al. Association of dietary factors and other coronary risk factors with social class in women in five Indian cities. Asia Pac J Clin Nutr 2000; 9: 298-302.

[42] Singh RB, Niaz MA, Beegom R, Wander GS, Thakur AS, Rissam HS. Body fat percent by bioelectrical impedence analysis and risk of coronary artery disease among urban men,with low rates of obesity: the Indian paradox. J Am Coll Nutr 1999; 18: 268-73.

[43] Gillum RF. Editorial, The epidemiology of cardiovascular disease in black Americans. N Engl J Med 1996; 335: 1597-9.

[44] Singal A, Fewtrel M, Cole TJ, Lucas A. Low nutrient intake and early growth for later insulin resistance in adolescents born preterm. Lancet 2003; 361: 1089-97.

[45] Singh RB, Niaz MA. Genetic variation and nutrition, in relation to coronary artery disease. J Assoc Physicians India 1999; 47: 1185-90.

[46] Singh RB, Rastogi SS, Niaz MA, et al. Effect of fat modified and fruits and vegetable enriched diets on blood lipids in the Indian diet heart study. Am J Cardiol 1992; 69: 869-74.
[47] Sack FM, Svetkey LP, Vollmer WM, et al. Effects on blood pressure of reduced dietary sodium and the Dietary Approaches to Stop Hypertension (DASH) diet. DASH-Sodium Collaborative Research Group. N Engl J Med 2001; 344: 3-10.

[48] Obarzanek E, Sacks FM, Vollmer WM, et al. Effects on blood lipids of a blood pressure-lowering diet: the Dietary Approaches to Stop Hypertension (DASH) Trial. Am J Clin Nutr 2001; 74: 80-9.

[49] Singh RB, Sharma VK, Gupta RK. Nutritional modulators of lipoprotein metabolism in patients with risk factors for coronary heart disease. J Am Coll Nutr 1992; 11: 391-8.

[50] Singh RB, Rastogi SS, Niaz MA, Ghosh S, Singh R. Effects of fatmodified and fruits vegetable enriched diets on blood lipids in the Indian diet heart study. Am J Cardiol 1992; 69: 869-74.

[51] Singh RB, Rastogi SS, Ghosh S, Singh R, Niaz MA. Effects of guava intake on serum total and high density lipoprotein cholesterol levels and on systemic blood pressure. Am J Cardiol 1992; 70: 1287-91.

[52] Singh RB, Rastogi SS, Ghosh S, Niaz MA, Singh NK. The diet and moderate exercise trial (DAMET): Results after 24 weeks. Acta Cardiol 1992; 48: 543-57.

[53] Singh RB, Rastogi SS, Sircar AR, Mani UV, Singh NK, Niaz MA. Effect of lifestyle changes on atherosclerotic risk factors in the Indian diet heart study. Am J Cardiol 1993; 71: 1283-8.

[54] Lioyd-Jones DM, Liu K, Colangilo LA, et al. Consistent or stable body mass index in young adulthood and longitudinal changes in metabolic syndrome components. The Coronary Artery Risk Development in Young Adult Study. Circulation 2007; 115:1004-11.

[55] Pella D, Dubnov G, Singh RB, Sharma R, Berry EM, Manor O. Effects of an Indo-Mediterranean diet on the omega-6/omega-3 ratio in patients at high risk of coronary artery disease: The Indian paradox. In: Simopoulos AP, Cleland LG, Karger, Eds. World Rev Nutr Diet 2003; 92: 74-80.

[56] Katcher HI, Legro RS, Kunselman AR, et al. The effects of whole grain- enriched hypocaloric diet on cardiovascular disease risk factors in men and women with metabolic syndrome. Am J Clin Nutr 2008; 87: 79-90.

[57] DeMeester F, Wild-type land based foods in health promotion and disease prevention: the LDL-CC:HDL-CC model. In: DeMeester F, Watson RR, Eds. Wild Type Foods in Health Promotion and Disease Prevention. Humana Press, NJ 2008; pp. 3-20.

[58] Fung TT, Chiuve SE, McCullough ML, Rexrode KM, Logroscino $\mathrm{G}, \mathrm{Hu}$ FB. Adherance to DASH- style diet and risk of coronary heart disease and stroke in women. Arch Intern Med 2008; 168: 713-20.

[59] Singh RB, DeMeester F, Mechirova V, Pella D, Otsuka K. Fatty acids in the causation and therapy of metabolic syndrome. In: DeMeester F, Watson RR, Eds. Wild Type Foods in Health Promotion and Disease Prevention. Humana Press, NJ 2008; pp. 263-84.

[60] Harris WS, Reid KJ, Sands SA, et al. Blood omega-3 and trans fatty acids in middle aged acute coronary syndrome patients. Am J Cardiol 2007; 99: 154-8

[61] Singh RB, Dubnov G, Niaz MA, et al. Effect of an IndoMediterranean diet on progression of coronary disease in high risk patients: a randomized single blind trial. Lancet 2002; 360: 145561.

[62] Simopoulos AP. Importance of the ratio of omega-6/omega-3 essential fatty acids:evolutionary aspects. World Rev Nutr Diet 2003; 92: 1-22.

[63] Storlien LH, Jenkins AB, Chisholm DJ, Pascoe WS, Khouri S, Kraegen EW. Influence of dietary fat composition on development of insulin resistance in rats . Relationsship to muscle triglyceride and omega-3 fatty acids in muscle phospholipid. Diabetes 1991; 40: $280-9$.

[64] Lardinois CK, Strarich GH. Polyunsaturated fats enhance peripheral glucose utilization in rats. J Am Coll Nutr 1991; 10: 340-5.

[65] Axen KV, Dikeakos A, Sclafani A. High dietary fat promotes syndrome $x$ in nonobese rats. J Nutr $2003 ; 133(7)$ : 2244-9.

[66] Hu FB, van Dam RM, Liu S. Diet and risk of type II diabetes: the role of types of fat and carbohydrate. Diabetologia 2001; 44: 80517.

[67] Vessby B, Unsitupa M, Hermansen K, et al. Substituting dietary saturated for monounsaturated fat impairs insulin sensitivity in 10 The Open Nutraceuticals Journal, 2010, Volume 3 Rastogi et al. healthy men and women: The KANWU Study. Diabetologia 2001; 44: 312-9. 
[68] Joint WHO/FAO Expert Consultation. Diet, Nutrition and the Prevention of Chronic Diseases,WHO,Geneva,WHO Technical Report Series, 916, 2003.

[69] Singh RB, Rastogi SS, Verma R, Bolaki L, Singh R, Ghosh S. An Indian experiment with nutritional modulation in acute myocardial infarction. Am J Cardiol 1992; 69: 879-85.

[70] Esposito K, Glugliano D. Diet and inflammation:a link to metabolic and cardiovascular diseases. Eur Heart J 2006; 27: 15-20.

[71] Vogel RA. Eating,vascular biology, and atherosclerosis: a lot to chew on. Eur Heart J 2006; 27: 13-4.

[72] Esposito K, Marfella R, Ciotola M, et al. Effect of a Mediterranean-style diet on endothelial dysfunction and markers of vascular inflammation in the metabolic syndrome: a randomized trial. JAMA 2004; 292: 1440-6.

[73] Esposito K, Nappo F, Glugliano F, Glugliano G, Martella R, Glugliano D. Effect of dietary antioxidants on postprandial endothelial dysfunction induced by a high fat meal in healthy subjects. Am J Clin Nutr 2003; 77: 139-43.

[74] Jiang Z, Sim JS. Consumption of omega-3 polyunsaturated fatty acids enriched eggs and changes in plasma lipids of human subjects. Nutrition 1993; 9: 513-8.

[75] De Lorgeril M, Salen P, Martin JL, Monjaud I, Delaye J, Mamelle $\mathrm{N}$. Mediterranean diet, traditional risk factors and the rate of cardiovascular complications after myocardial infarction. Final report of the Lyon Diet Heart Study. Circulation 1999; 99: 779-85.

[76] Singh RB, Pella D, DeMeester F. What to eat and chew in acute myocardial infarction. Eur Heart J 2006; 27: 1628-29.

[77] The 2008 Physical Activity Guidelines for Americans. The U.S. Department of Health and Human Services (HHS) issues the Physical Activity Guidelines for Americans. The content of the Physical Activity Guidelines complements the Dietary Guidelines for Americans, a joint effort of HHS and the U.S. Department of Agriculture (USDA). http://www.health.gov/PAGuidelines/.

[78] Cornelissen G, Chen CH, Halberg F. Predictive value of blood pressure variability: relative merits of circadian parameters versus dipping patterns. N Engl J Med 2006; 355: 850-1.

[79] Kumar S, Mukherjee S, Mukhopadhya P, et al. Prevalence of diabetes and impaired glucose intolerance in a selected population with special reference to influence of family history and anthropometric measurements-The Kolkata Policeman study. J Assoc Physicians India 2008; 56: 841-4

[80] Vargova V, Mechirova V, Fedacko J, Pella D, De Meester F, Singh RB. Can nuts consumption modulate cardiovascular disease: report of a case with review of literature. Open Nutra J 2010 (in press).

[81] Singh RB, De Meester F, Pella D, Basu TK, Watson R. Globalization of dietary wild foods protect against cardiovascular disease and all cause mortalities? A Scientific statement from the International College of Cardiology, Columbus Paradigm Institute and the International College of Nutrition. Open Nutra J 2009; 2: 42-5.

[82] Singh RB, Wilczynska- Kwiatek A, Fedacko J, Pella D, De Meester F. Pranayam: The power of breath. Int J Disab Human Dev 2009; 8: 141-53.

[83] Singh S, Singh G, Kartikey K, Singh RB. In: Handbook of Pulmonary diseases. In: Fodork, Toth A, Eds. Nova Science Publishers 2009; pp. 1-9.

[84] Mishra S, Singh RB, Dwivedi SP, et al. Effects of nutraceuticals on gene expressions. Open Nutra J 2009; 2: 70-80.

[85] Kwiatek AW, Singh RB, De Meester F. Nutrition and behaviour: the role of w-3 fatty acids. Open Nutra J 2010; 3: 119-28.

[86] Singh RB, De Meester F, Juneja L, et al. The evolution of low W$6 / \mathrm{W}-3$ ratio dietary pattern and risk of cardiovascular disease and diabetes mellitus. J Altern Med Res 2011; 3(1) (in press)

[87] World Health Organization. Fact sheet no. 312: what is diabetes? Available at: http://www.who.int/mediacentre/ factsheets/fs312/en/. Accessed October 16, 2009.

[88] Singh RB, Verma SP, Niaz MA. Social class and coronary artery disease in India. Lancet 1999; 353: 154-5.

[89] Singh RB, De Meester F, Wilkzynska A. The Tsim Tsoum Approaches for Prevention of Cardiovascular Disease. Cardiol Res Pract 2010; 2010: 824938 .

[90] Singh RB, Rastogi SS, Goyal RK, et al. Social class, food intakes and risk of coronary artery disease in the developing world: The Asian paradox. Modern Dietary Fat Intake in Disease Promotion, In: De Meester F, Zibedi S, Watson RR, Eds. Press 2010, pp. 43-70.

(C) Rastogi et al.; Licensee Bentham Open.

This is an open access article licensed under the terms of the Creative Commons Attribution Non-Commercial License (http://creativecommons.org/licenses/ by-nc/3.0/) which permits unrestricted, non-commercial use, distribution and reproduction in any medium, provided the work is properly cited. 